\title{
Sinusitis maxillaris mint a fogászati cone-beam komputertomográfiás vizsgálat melléklelete
}

\author{
Schreindorfer Károly dr. ${ }^{1}$ - Kiss Ágnes dr. ${ }^{2}$ - Marada Gyula dr. ${ }^{3}$ \\ Pécsi Tudományegyetem, Klinikai Központ \\ ${ }^{1}$ Fogászati és Szájsebészeti Klinika, Konzerváló Fogászati és Parodontológiai Tanszék, \\ ${ }^{2}$ Fogászati és Szájsebészeti Klinika, ${ }^{3}$ Fogászati és Szájsebészeti Klinika, Fogpótlástani Tanszék, Pécs
}

\begin{abstract}
Bevezetés: A cone-beam komputertomográfia elterjedt a fej-nyaki régió diagnosztikájában. Ezeken a felvételeken gyakran észlelhető a sinus maxillaris nyálkahártyájának megvastagodása.

Célkitüzés: Az odontogen sinusitis maxillaris okaként azonosítható fogak és foggyökerek előfordulási arányának meghatározása és a felvételeken látható átlagos mucosamegvastagodás rögzítése.

Módszer: A vizsgálat alapjául szolgáló felvételek a Pécsi Tudományegyetem Fogászati és Szájsebészeti Klinikáján készültek 2015-2016 között. A felvételek voxelmérete 0,25-0,4 mm között változott, a képmező mérete $15 \times 12 \mathrm{~cm}$ volt. Az akvizíciós idő pedig maximum 27 másodperc volt.

Eredmények: Az átnézett 260 felvétel közül 170 eset tett eleget a kiindulási kritériumoknak. Az átlagos mucosavastagság 8,8 mm-nek adódott. Jelen vizsgálatban a felső első molarisok palatinalis és a második molarisok mesiobuccalis gyökere asszociálódott leggyakrabban odontogen sinusitis maxillaris kórképéhez.

Következtetés: A szokványos terápiára nem vagy csak átmenetileg reagáló krónikus sinusitis maxillaris esetén indokolt lehet fogorvosi konzílium, és cone-beam komputertomográfiás felvétel készítése dentalis góc kizárása végett.

Orv Hetil. 2017; 158(44): 1747-1753.
\end{abstract}

Kulcsszavak: cone-beam komputertomográfia, odontogen sinusitis, mucosamegvastagodás, felső első molaris, felső második molaris

\section{Maxillary sinusitis as a diagnostical adverse finding of the dental cone-beam computed tomography study}

Introduction: Cone-beam computed tomography is a frequently used diagnostical method in the head and neck region. The thickening of the maxillary sinus mucosa is often observed in these images.

Aim: Determining the prevalence of teeth and roots that can be identified as cause of maxillary odontogenic sinusitis, and recording the average observed mucosa thickening on these images.

Method: The scans that give the base of the study have been performed by the Department of Dentistry of Medical University of Pécs between 2015-2016. The size of the voxels had been varied between 0.25 and $0.4 \mathrm{~mm}$ and the size of the image had been set up to $15 \times 12 \mathrm{~cm}$. The acquisition time had been set up to 27 seconds.

Results: 170 cases of the 260 revised records fulfilled the initial criterion conditions. The average mucosa thickness was $8.8 \mathrm{~mm}$. During the present study, the upper first molars palatal and the second molars mesiobuccal roots were mainly associated with maxillary odontogenic sinusitis.

Conclusion: Whether in the case of chronic maxillary sinusitis that is not or only temporarily responsive to conventional therapy, may it be justifiable to provide dental consultation and cone-beam computed tomography to exclude the dental origin of sinusitis.

Keyworlds: cone-beam computed tomography, odontogenic sinusitis, mucosa thickening, upper first molar, upper second molar

Schreindorfer K, Kiss Á, Marada Gy. [Maxillary sinusitis as a diagnostical adverse finding of the dental cone-beam computed tomography study]. Orv Hetil. 2017; 158(44): 1747-1753.

(Beérkezett: 2017. augusztus 10; elfogadva: 2017. szeptember 13.) 


\section{Rövidítések}

$\mathrm{CBCT}=$ (cone-beam computed tomography) cone-beam komputertomográfia; $\mathrm{CT}=$ (computed tomography) komputertomográfia; FOV = (field of view $)$ képmező; OSM = odontogen sinusitis maxillaris

A modern fogászatban a pontos diagnózis és a korrekt mûtéti tervezés alapja a precíz és informatív képalkotó diagnosztika, amelynek fó reprezentánsa a cone-beam komputertomográfia (CBCT) technológia. A CBCT vagy más néven digitális volumentomográfia kifejlesztését lényegében a hagyományos komputertomográfokkal egy időben kezdték meg az 1980-as években. A sorozatos fejlesztéseknek köszönhetően mára a CBCT-technológia általánosan hozzáférhető; a fogászat valamennyi területén, valamint a fül-orr-gégészet és fej-nyaki sebészetben is egyre gyakrabban alkalmazott képalkotó módszer. A hagyományos CT-készülékekkel összevetve az alábbi előnyökkel rendelkezik: CT-ekvivalens képmino”ség, a CT-készülékeknél kisebb sugárdózis, a kis mütőkben, rendelőkben is tolerálható kompakt méret, valamint a CT-készülékeknél jóval alacsonyabb ár és szervizköltség [1-3].

A jelenleg elérhető készülékek átlagos ábrázolási felbontása 0,4-0,076 mm közötti, ami 1,25-6,5 vonalpár/ mm-nek felel meg [4]. Ez rosszabb, mint a hagyományos röntgenfelvételek felbontása, ami hozzávetőleg 20 vonalpár/mm. Mivel azonban a CBCT három dimenzióban ábrázol, ezért eliminálja az anatómiai képletek egymásra vetüléséből adódó úgynevezett anatómiai zajokat. A felvételek összességében tehát részletgazdagabb ábrázolással rendelkeznek, mint a kétdimenziós röntgentechnikák. Ennek köszönhető, hogy többek közt a sinus maxillaris nyálkahártya-vastagsága is specifikusabban ítélhető meg [5].

A különböző fogászati indikációval (endodontiai, implantológiai, parodontológiai stb.) a maxilláról készített felvételeken gyakran látható a sinus maxillaris nyálkahártyájának több mint $2 \mathrm{~mm}$-es megvastagodása, amely asszociálódhat periapicalis patológiával (potenciálisan odontogen eredetû́ elváltozás), illetve megjelenhet önálló entitásként is (nem odontogen eredetű elváltozás) [6]. A szájüregi képletekről (fogak, parodontium, szájnyálkahártya) a sinus maxillarisra terjedő gyulladást és az így kialakult nyálkahártya-megvastagodást tekintjük odontogen eredetű sinusitis maxillarisnak. A gyulladás az anatómiai viszonyok miatt többnyire közvetlenül terjed rá a sinusra. Az odontogen sinusitis maxillarist (OSM) kiváltó foobb fogászati elváltozásokat foglalja össze az 1 . táblázat.

Az OSM előfordulását sokáig 10-12\% közé tette az irodalom az összes vizsgált sinusitis maxillaris eset között [7]. Az újabb irodalmi hivatkozások szerint ez az érték 4,6-47\% között változhat, amely részben a diagnosztikus módszerek különbözőségével, az eltérő beteganyaggal és az eltérő földrajzi elhelyezkedéssel is magyarázható [5].
1. táblázat | Odontogen sinusitist provokáló dentalis eredetű elváltozások

Pulpalis fertőzésekből származó periapicalis folyamatok

Parodontitis diffusa

Osteomyelitis, periostitis

Impaktált, retineált fogak gyulladásai vagy cystái

Radicularis vagy residualis cysta

Gyökérkezelés

Oroantralis kommunikáció

Idegen test

Traumák

Dentoalveolaris mütétek

Odontogen tumorok

Az OSM tünettanát illetően megállapítható, hogy (hasonlóan más krónikus sinusitishez) viszonylag tünetszegény, és általában egyoldali elváltozás [8]. Leggyakoribb tünetként az orrdugulás szerepel, de az esetek körülbelül egyharmadában ez is hiányozhat. A fogfájás (tompa kvalitású bizonytalan érzet, esetleges ráharapási érzékenységgel) mint tünet kórjelző lehet, de szintén nem megbízható jel [9]. A szegényes és sokszor bizonytalan eredetű tüneteknek köszönhetően az odontogen eredetû sinusitisek ezért krónikusan fennállhatnak és gócpozitív állapotot tarthatnak fent a pácienseknél.

Az OSM kezelésének alapja, hogy a fogászati eltérést és a sinusitist egyszerre kell kezelni, mert csak így kerülhető el a recidíva. A góc szanálása az esetek 95\%-ában megoldja a sinusitist [5]. Az extrakció, az érintett fog gyökérkezelése vagy gyökércsúcs-reszekciója és a széles spektrumú antibiotikus kezelés mellett szükség lehet a sinusban lévő idegen test (foggyökér) endoszkópos úton történő eltávolítására is. Ha az infundibulotomia nem elégséges, külső feltárásból kell az arcüreget kitisztítani.

A megnyílt sinus gyakori következménye a fogászati beavatkozásoknak, a sinus apertus esetek többsége iatrogén eredetú. Az esetek egy része észrevétlen marad, és később spontán záródik. A felső első molarist érintő beavatkozásoknál nyílik meg leginkább a sinus [10]. Ehhez hozzájárul, hogy a maxillaris első molaris nagyméretü, extrakció után a thrombus nem mindig tud szervülni. Az oroantralis kommunikáció idővel elkerülhetetlenül a sinus gyulladásának krónikus forrása lesz, ilyenkor már nem elég zárni a sinust, de a gyulladást is mütétileg kell megoldani [11]. A sinus recessusaiba benyúló molarisok eltávolításakor előfordul, hogy csak a csontos arcüreg nyílik meg, ilyenkor a nyálkahártyazsák ép, tehát a kóros kommunikáció nem jön létre. Ép nyálkahártya esetén a sinus zárása nem szükséges. Perforált mucosa esetén viszont azonnal vagy halasztott formában, de kötelező. A nem kellő időben zárt defektusok oroantralis fistulává alakulhatnak, amelyeket mucosaepithel borít. 


\section{Célkitüzés}

Retrospektív tanulmányunk célja volt, hogy meghatározzuk az odontogen eredetû sinusitis maxillaris CBCTfelvételeinek radiológiai jellegzetességeit és megvizsgáljuk anyagunkban az érintett fogak gyakoriságát. A felvételeken látott radiomorfológiai eltéréseket az elérhető irodalom alapján kategóriákba soroltuk és vizsgáltuk az adott mucosamegvastagodás mértékét is. A szerzők tudomása szerint ilyen vizsgálatot Magyarországon még nem végeztek.

\section{Módszer}

A három szerző összesen 260 CBCT-felvételt tekintett át, amelyek a Pécsi Tudományegyetem, Fogászati és Szájsebészeti Klinikán készültek a 2015-2016 közötti időintervallumban. Kiindulási kritériumként fogalmaztuk meg, hogy a felvétel mérete megfelelő legyen a teljes maxilla vizsgálatához $(15 \times 12 \mathrm{~cm})$, illetve minimálisan egyegy fog jelenlétét a felső kvadránsokban. Kizártuk azokat a felvételeket, amelyeken fogatlan volt a maxilla vagy a processus alveolaris maxillae területén elmozdulás, sugárkeményedés, illetve más mütermék volt látható, vagy nem látszódott a maxilla teljes területe, mert a kiindulási indikáció kis volumenú, nagy intenzitású felvételt indokolt (például endodontiai okból készült felvétel). Így összesen 170 felvétel tett eleget a kiindulási kritériumoknak, ezért ezeket választottuk be a vizsgálatba.

A betegek életkora 21 évtől 67 évig terjedt, átlagéletkoruk 51,3 év (SD: $\pm 11,6)$ volt. A vizsgált betegek közül 68 volt a nő és 102 a férfi páciens. A CBCT-felvételek dentomaxillofacialis volument ábrázoló rendszerrel (NNT), NewTom 5G (QR Verona, Verona, Olaszország) készülékkel történtek (360 rotáció, pulzáló mód). A képrekonstrukciós szoftver NNT viewer (QR Verona, Verona, Olaszország) volt. A felvételek voxelmérete 0,25-0,4 mm között változott, a képmező (field of view; FOV) $15 \times 12 \mathrm{~cm}$ volt. Az akvizíciós idő 27 másodperc vagy annál kevesebb volt.

A szerzők annak érdekében, hogy a vizsgált felvételekről minél homogénebb véleményt alkothassanak, konszenzusmegbeszélésen vettek részt. Ennek keretében 20 olyan CBCT-felvételt értékeltek közösen, amelyek sinus maxillaris státusza vagy negatív volt, vagy korábban sinusitis maxillaris diagnózist kapott. Ezután a 170 előzőleg kiválasztott felvételt a szerzők külön-külön leletezték. A felvételek megjelenítéséhez 24 inch átmérőjü, 1920 × 1200 felbontású Dell (Dell Corporation, Round Rock, Texas, Amerikai Egyesült Államok) monitort használtak. A jelzett Cohen-féle kappa-mutatója 0,9 feletti értéket mutatott, így megállapíthattuk, hogy a vizsgálók között teljes volt az egyetértés. Minden felvételt axiális, frontalis és sagittalis síkban is megvizsgáltak, hogy azokat a fogakat és gyökereket külön-külön feljegyezhessék, amelyek OSM okaként szerepelhettek.
Az irodalomban jelenleg nincs konszenzus abban a tekintetben, hogy mekkora mucosavastagságot tekintsünk kórosnak. A szerzők egy része már az 1 mm-nél vastagabb nyálkahártyát is megvastagodottnak tekinti [12, 13], mások csak a 3 mm-nél nagyobb nyálkahártya-vastagságot gondolják kórosnak [14, 15].

Krónikus periapicalis periodontitis esetén a periapicalis térbe jutott bakteriális flóra lokális irritáló hatása is sinusnyálkahártya-megvastagodást okozhat helyileg, tényleges OSM nélkül (fals pozitív eseteket generálhat); ezért vizsgálatunkban a $2 \mathrm{~mm}$-nél nagyobb nyálkahártya-megvastagodást tekintettük kórosnak, összhangban a Ren és mtsai által leírtakkal [16].

A rendelkezésre álló szakirodalom alapján egy kritériumrendszert alkalmaztunk (Abrahams- és Glassberg-féle osztályozás) az eltérő etiológiájú sinusitis maxillarisok diagnosztizálására [17]. Ezt az osztályozást módosítva az előforduló sinusitises eseteket négy csoportba osztottuk.

Az egyes csoportokat szemléltető ábrák és CBCT-felvételek (1. ábra $A-J)$ is bemutatják.

\section{Ép sinus}

Ebben az esetben a sinuson nincs nyálkahártya-megvastagodás vagy egységesen megvastagodott, de ennek mértéke $2 \mathrm{~mm}$ alatti. A maxilla fogai lehetnek egészségesek, cariesesek, nyitott pulpakamrájúak, helyreállítottak vagy extraháltak, radiológiailag igazolt vagy kétes periapicalis laesióval (1. ábra $A-C$ ).

\section{Odontogen eredetü sinusitis}

A sinuson belül elhelyezkedő lágyrész-denzitású masszát abban az esetben tekintjük odontogen eredetünek, ha a felsorolt kritériumoknak megfelel: carieses fog, rosszul helyreállított fog vagy extrakciós hely radiológiailag igazolt vagy kétséges periapicalis laesióval abban az esetben, ha a mucosa vastagsága nagyobb, mint $2 \mathrm{~mm}$ és a szóban forgó fogra vagy extrakciós helyre lokalizált (1. ábra D és E).

\section{Nem odontogen eredetü sinusitis}

A sinuson belül elhelyezkedő lágyrész-denzitású masszát abban az esetben tekintjük nem odontogen eredetünek, ha a felsorolt kritériumoknak megfelel: A fogak nem cariesesek, coronalis és/vagy endodontiai helyreállításuk jó minőségü, nincs radiológiailag igazolt periapicalis laesio. Ha extrakció után az alveolus intakt vagy gyógyuló és a mucosa megvastagodása nem szorítkozik egyik fogra sem (1. ábra F-H).

\section{Feltehetôen kevert etiológiájú sinusitis}

A sinuson belül elhelyezkedő lágyrész-denzitású masszát abban az esetben tekintjük kevert etiológiájú sinusitisnek, ha a felsorolt kritériumoknak megfelel: carieses fog, rosz- 

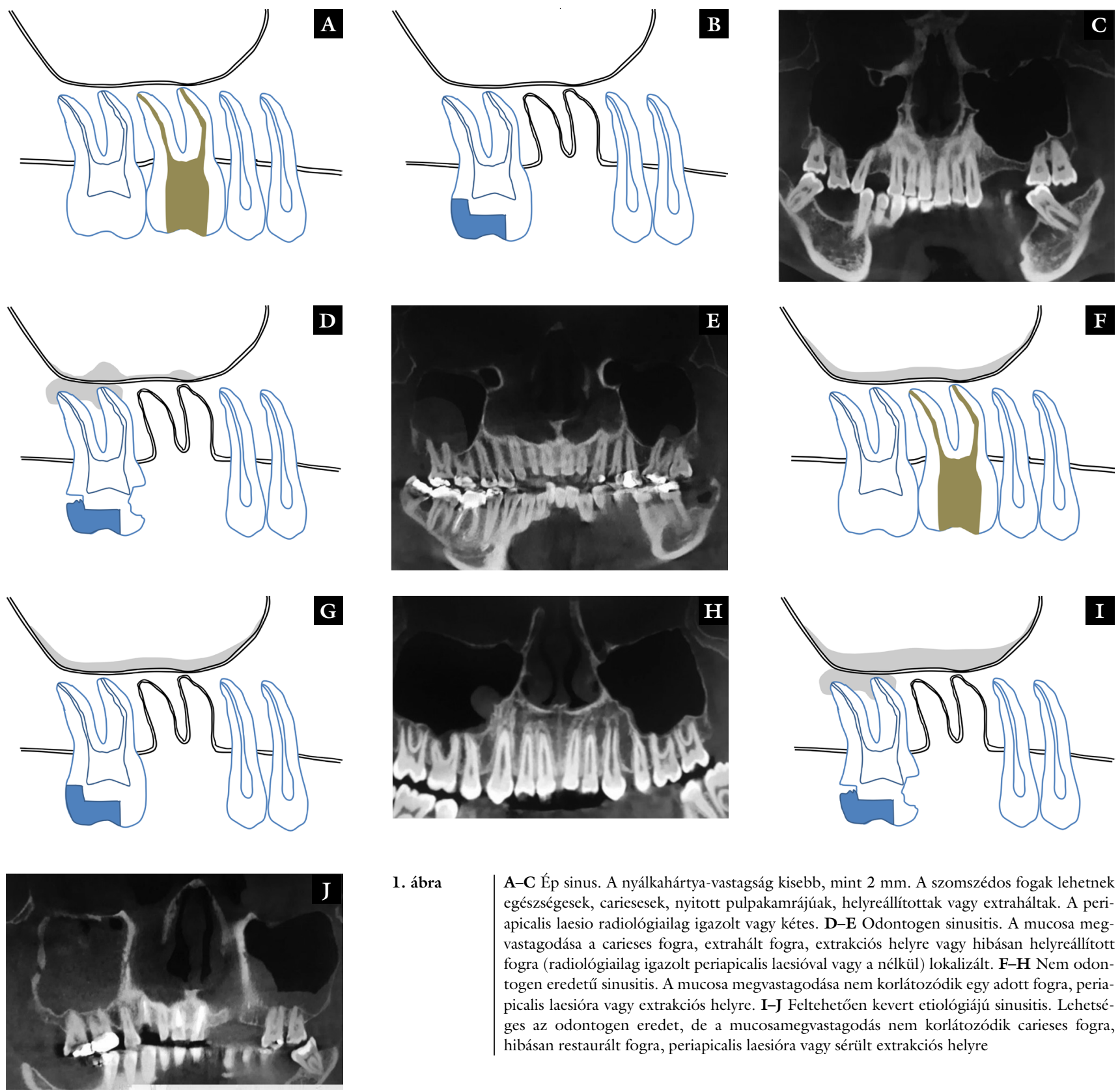

1. ábra

A-C Ép sinus. A nyálkahártya-vastagság kisebb, mint $2 \mathrm{~mm}$. A szomszédos fogak lehetnek egészségesek, cariesesek, nyitott pulpakamrájúak, helyreállítottak vagy extraháltak. A periapicalis laesio radiológiailag igazolt vagy kétes. D-E Odontogen sinusitis. A mucosa megvastagodása a carieses fogra, extrahált fogra, extrakciós helyre vagy hibásan helyreállított fogra (radiológiailag igazolt periapicalis laesióval vagy a nélkül) lokalizált. F-H Nem odontogen eredetû sinusitis. A mucosa megvastagodása nem korlátozódik egy adott fogra, periapicalis laesióra vagy extrakciós helyre. I-J Feltehetően kevert etiológiájú sinusitis. Lehetséges az odontogen eredet, de a mucosamegvastagodás nem korlátozódik carieses fogra, hibásan restaurált fogra, periapicalis laesióra vagy sérült extrakciós helyre

szul helyreállított fog, periapicalis laesio vagy roncsolt alveolus (illetve ezek kombinációja), de a nyálkahártya megvastagodása nem lokalizálható egyik fog területére sem, hanem kiterjedtebb, akár a nem odontogen sinusitisre jellemzően kétoldali lokalizációjú (1. ábra I és J).

Odontogen sinusitis esetén külön feljegyeztük az etiológiai tényezőként megjelölt fogak és a periapicalis laesióhoz (amennyiben jelen volt) kapcsolható foggyökerek számát, és ezek eloszlását. Ha a fog előzőleg endodontiai kezelésben részesült, ezt is feljegyeztük. Rögzítésre került az is, hogy mennyire megtartott a sinus alapja, valamint lateralis és medialis fala, és hogy van-e a csonton bármilyen morfológiai eltérés vagy meszesedés.

A sinusitises csoportok esetén rögzítésre került a nyálkahártya átlagos vastagsága és ezek szórása is.

\section{Eredmények}

A szerzők az átnézett 260 CBCT-felvétel közül a kiindulási kritériumoknak megfelelően 170 felvételt választottak be a vizsgálatukba. Ezen a 170 felvételen 201 olyan lokalizált radiológiai tünetegyüttest (a továbbiakban radiológiai eset) azonosítottak, ahol egy adott fog gyökere és a hozzá közvetlenül kapcsolódó sinusmucosa megvastagodása potenciálisan odontogen sinusitist kiváltó tényező lehetett. Ebből a 201 radiológiai esetből 145-ben olyan gócos fogakat azonosítottak, amelyek elváltozásai nagy valószínúséggel befolyásolták a sinus maxillaris bázisának integritását.

A 145, potenciálisan odontogen radiológiai eset közül két esetben első praemolaris, 17 alkalommal második 
praemolaris, 82 alkalommal első molaris, 41 alkalommal második molaris, három alkalommal harmadik molaris fog volt érintett. A 145, valószínűsíthetően odontogen radiológiai esetből 103-at az odontogen sinusitis, míg 42-t a kevert etiológiájú sinusitis formába soroltunk, mivel a sinusitis nem csak a jól körülírt beteg, vagy rosszul restaurált fogra korlátozódott. A vizsgált 201 radiológiai esetből 56 volt nem odontogen eredetü.

Az odontogen és kevert etiológiájú sinusitises eseteket (második és negyedik csoport) együttesen vizsgálva (145 eset) a nyálkahártya-megvastagodás jóval nagyobb arányban - hatszor gyakrabban - volt köthető a molarisokhoz (összesen 126 eset), mint a praemolarisokhoz (összesen 19 eset).

A sinusitis (odontogen + kevert etiológiájú) kialakulásában részt vevő fogcsoportok eloszlását szemlélteti a 2. ábra.

A szerzók vizsgálatukban feljegyezték, hogy milyen arányban szerepeltek az egyes foggyökerek a sinusitis létrejöttében. Az első praemolarisok csoportjában egy esetben a buccalis, a másik esetben a palatinalis gyökér volt érintett. A sinusitist kiváltó 17 második praemolaris közül 15 egygyökerû́ volt. A maradék két fog esetén az egyiknél a buccalis, a másiknál mindkét gyökér hozzájárult az OSM kialakulásához. Az első molarisok csoportjában (82 fog) 57 palatinalis, 27 mesiobuccalis és 25 distobuccalis gyökér; míg a második molarisok csoportjában (41 fog) 33 mesiobuccalis, 11 palatinalis és 10 distobuccalis gyökér asszociálódott a sinus maxillaris odontogen eredetű patológiájával (3. ábra). A harmadik molarisok közül (három fog) két esetben a mesialis gyökér, egy esetben a distalis gyökér volt köthető a sinusnyálkahártya megvastagodásához.

$\mathrm{Az}$ átlagos mucosavastagság a nem odontogen sinusitis csoportban (harmadik csoport) volt a legmagasabb (12,8 $\pm 8,4 \mathrm{~mm}$ ), míg az odontogen sinusitis csoportban (második csoport) a legalacsonyabb $(6,68 \pm 4,2 \mathrm{~mm})$. A kevert etiológiájú sinusitis csoportban (negyedik csoport) az átlagérték a másik két csoport között helyezkedett el $(9,54$ $\pm 4,8 \mathrm{~mm}$ ) (4. ábra).

A második, a harmadik és a negyedik csoport összesített átlagos mucosavastagsága 8,8 mm-nek adódott.

A sinusitishez köthető összes (145) fog közül 31 fognál történt korábban gyökérkezelés, és a 31 fogból háromnál volt jelen kipréselődött gyökértömő anyag (sealer és/vagy guttapercha).

\section{Megbeszélés}

A periapicalis gyulladás sinus maxillarisra történő átterjedését már Bauer bizonyította 1943-ban [18]. A periapicalis gyulladásról kimutatta, hogy képes ráterjedni a sinus nyálkahártyájára, akár a sinus csontos alapjának perforálásával is.

Jelen retrospektív tanulmányunk célja volt, hogy meghatározzuk az odontogen eredetü sinusitis maxillaris CBCT-felvételeinek radiológiai jellegzetességeit és elő-

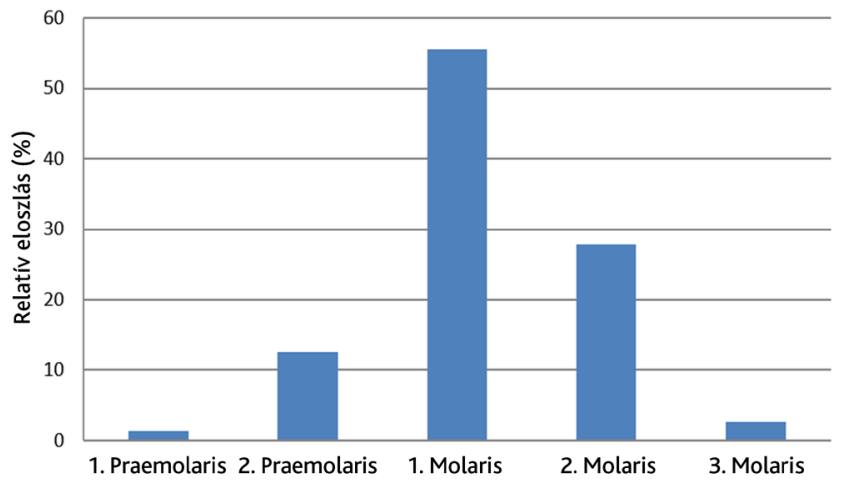

2. ábra $\quad$ A lokális mucosamegvastagodást okozó fogak arányának megoszlása. A kiindulási kritériumrendszernek megfelelő második és negyedik csoport együttesen szerepeltetve

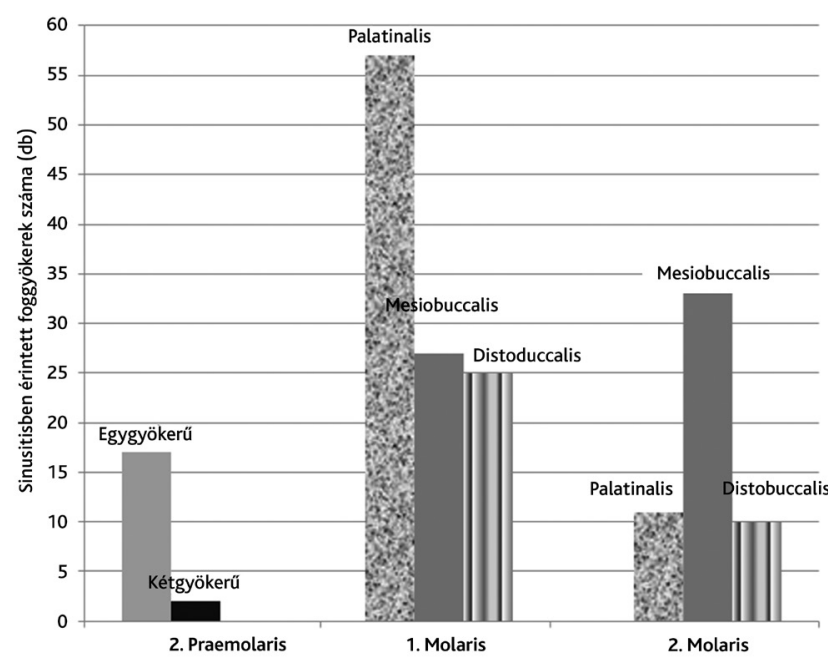

3. ábra $\quad$ A lokális mucosamegvastagodáshoz (odontogen és kevert sinusitis) köthető foggyökerek megoszlása

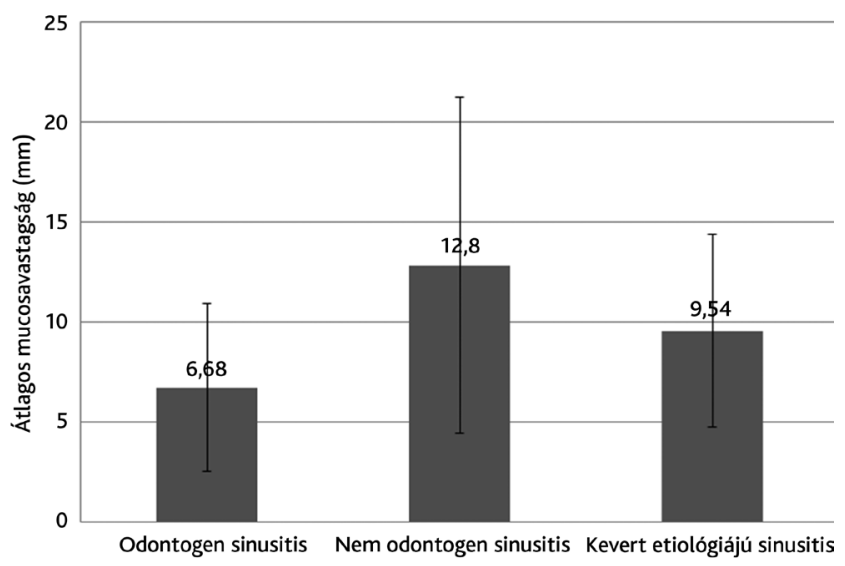

4. ábra $\mid$ A sinusnyálkahártya-vastagságok átlagértékei és szórásai a kiindulási kritériumrendszernek megfelelő második, harmadik és negyedik csoportokban

fordulási gyakoriságát. Az odontogen eredetű sinusitisek diagnosztizálásához adaptáltunk egy, a CBCT-felvételek értékeléséhez használható kritériumrendszert. Az általunk megfogalmazott kritériumok az Abrahams-és Glassberg-féle osztályozás módosításának tekinthetők [17]. 
Az Abrahams és Glassberg - mindketten radiológusok által készített klasszifikáció széles körben használatos a klinikai gyakorlatban. Tanulmányunkban azt a sinusitist tekintettük odontogen eredetúnek, ahol egy adott fog elváltozásához kapcsolódóan a nyálkahártya lokálisan megvastagodott. A fogak közül a maxilla első molarisai szerepeltek leggyakrabban kiváltó tényezóként, összhangban korábbi irodalmi közlésekkel $[19,20]$. Ezen szerzők azonban nem vizsgálták, hogy melyik foggyökér és milyen százalékban érintett a sinusitis kialakulásában.

Saját vizsgálataink alapján az első molaris fog palatinalis gyökere szerepelt leggyakrabban a sinus alapjának perforálásában. Ebben az a meglepő, hogy nem az első molaris palatinalis gyökere a sinushoz legközelebb elhelyezkedő gyökér. A felső második molaris mesiobuccalis gyökere átlagosan 0,67 mm-rel közelebb van a sinushoz, mint az első molaris palatinalis gyökere [21]. A két fog közül az első molaris négy-öt évvel korábban mutat áttörési tendenciát, így sokkal jobban kitett a cariesnek és következményes megbetegedéseinek, mint a második molaris. Azt tapasztaltuk, hogy a második molaris érintettsége esetén a mesiobuccalis gyökér laesiója a leggyakoribb kóroki tényező. Az is figyelemre méltó, hogy a sinus bázisán minden esetben a corticalis csont destrukcióját észleltük, amikor fogászati etiológia is jelen volt.

\section{Következtetés}

A vizsgált felvételek alapján kijelenthetó, hogy az odontogen sinusitis maxillaris sajnos nem ritka kórkép. Az irodalmi adatok alapján ezek az elváltozások általában krónikusan fennálló folyamatok. Ez részben azzal magyarázható, hogy relatíve tünetszegény gyulladást okoznak, másrészt általában egyoldali és a kiváltó fog környezetéhez asszociált lokális elváltozások a sinus maxillarisban [22].

Felismerésük így diagnosztikus kihívásokat okozhat mind a fül-orr-gégésznek, mind a fogorvosnak. A fogorvos szemszögéből a maxilla molarisainak gócos állapota (periapicalis és/vagy parodontalis érintettsége), a fülorr-gégész szemszögéből a szokványos fül-orr-gégészeti terápiára nem vagy csak átmenetileg reagáló krónikus elváltozások vethetik fel a lehetőségét odontogen sinusitis maxillarisnak. Ez utóbbi esetben pedig a gyógyulás érdekében fogorvosi vizsgálat, konzílium és kezelés is indokolt, esetenként pedig CBCT-felvétel készítése is [23].

Anyagi támogatás: A közlemény megírása, illetve a kapcsolódó kutatómunka anyagi támogatásban nem részesült.
Szerzői munkamegosztás: A munka a szerzők közös érdeme. A cikk végleges változatát valamennyi szerző elolvasta és jóváhagyta.

Érdekeltségek: A szerzőknek nincsenek érdekeltségeik.

\section{Irodalom}

[1] Arai Y, Tammisalo E, Iwai K, et al. Development of a compact computed tomographic apparatus for dental use. Dentomaxillofac Radiol. 1999; 28: 245-248.

[2] Mozzo P, Procacci C, Tacconi A, et al. A new volumetric CT machine for dental imaging based on the cone-beam technique: preliminary results. Eur Radiol. 1998; 8: 1558-1564.

[3] Nemtoi A, Czink C, Haba D, et al. Cone beam CT: a current overview of devices. Dentomaxillofac Radiol. 2013; 42: 20120443

[4] Scarfe WC, Levin MD, Gane D, et al. Use of cone beam computed tomography in endodontics. Int J Dent. 2009; 2009: 634567.

[5] Longhini AB, Ferguson BJ. Clinical aspects of odontogenic maxillary sinusitis: a case series. Int Forum Allergy Rhinol. 2011; 1: $409-415$.

[6] Rege IC, Sousa TO, Leles CR, et al. Occurrence of maxillary sinus abnormalities detected by cone beam CT in asymptomatic patients. BMC Oral Health 2012; 12: 30.

[7] Maloney PL, Doku HC. Maxillary sinusitis of odontogen origin. J Can Dent Assoc. 1968; 34: 591-603.

[8] Bjork H. On stomatic (dental) maxillary sinusitis. Odontol Tidskr. 1949; 57: 113-122.

[9] Troeltzsch M, Pache C, Troeltzsch M, et al. Etiology and clinical characteristics of symptomatic unilateral maxillary sinusitis: A review of 174 cases. J Craniomaxillofac Surg. 2015; 43: 15221529.

[10] Amaratunga NA. Oro-antral fistulae - a study of clinical, radiological and treatment aspects. Br J Oral Maxillofac Surg. 1986; 24: 433-437.

[11] Németh Zs, Bogdán S. Diagnostics and treatment of sinus apertus. [A sinus apertus diagnosztikája és kezelése.] Dental Hírek 2009; 5: 24-26. [Hungarian]

[12] Ritter L, Lutz J, Neugebauer J, et al. Prevalence of pathologic findings in the maxillary sinus in cone-beam computerized tomography. Oral Surg Oral Med Oral Pathol Oral Radiol Endod. 2011; 111: 634-640.

[13] Phothikhun S, Suphanantachat S, Chuenchompoonut V, et al. Cone-beam computed tomographic evidence of the association between periodontal bone loss and mucosal thickening of the maxillary sinus. J Periodontol. 2012; 83: 557-564.

[14] Nair UP, Nair MK. Maxillary sinusitis of odontogenic origin: cone-beam volumetric computerized tomography-aided diagnosis. Oral Surg Oral Med Oral Pathol Oral Radiol Endod. 2010; 110: e53-e57.

[15] Nunes CA, Guedes OA, Alencar AH, et al. Evaluation of periapical lesions and their association with maxillary sinus abnormalities on cone-beam computed tomographic images. J Endod. 2016; 42: 42-46.

[16] Ren S, Zhao H, Liu J, et al. Significance of maxillary sinus mucosal thickening in patients with periodontal disease. Int Dent J. 2015 ; 65: 303-310.

[17] Abrahams JJ, Glassberg RM. Dental disease: a frequently unrecognized cause of maxillary sinus abnormalities? AJR Am J Roentgenol. 1996; 166: 1219-1223.

[18] Bauer WH. Maxillary sinusitis of dental origin. Am J Orthod Oral Surg. 1943; 29: B133-B151. 
[19] Arias-Irimia O, Barona-Dorado C, Santos-Marino JA, et al. Meta-analysis of the etiology of odontogenic maxillary sinusitis. Med Oral Patol Oral Cir Bucal 2010; 15: e70-e73.

[20] Obayashi N, Ariji I, Goto M. Spread of odontogenic infection originating in the maxillary teeth: computerized tomographic assessment. Oral Surg Oral Med Oral Pathol Oral Radiol Endod. 2004; 98: 223-231.

[21] Eberhardt JA, Torabinejad M, Christiansen EL. A computed tomographic study of the distances between the maxillary sinus floor and the apices of the maxillary posterior teeth. Oral Surg Oral Med Oral Pathol. 1992; 73: 345-346.
[22] Matsumoto Y, Ikeda T, Yokoi H, et al. Association between odontogenic infections and unilateral sinus opacification. Auris Nasus Larynx 2015; 42: 288-293.

[23] Longhini AB, Branstetter BF, Ferguson BJ. Unrecognized odontogenic maxillary sinusitis: a cause of endoscopic sinus surgery failure. Am J Rhinol Allergy 2010; 24: 296-300.

(Schreindorfer Károly dr., Pécs, Dischka Győző u. 5., 7621 e-mail: sch.karesz@gmail.com)

\section{Rácz Károly Endokrinológiai Továbbképző Tanfolyam Budapest, 2017. november 30. - december 2. NOVOTEL Centrum, 1088 Budapest, Rákóczi út 43-45.}

\section{Köszöntő}

A Semmelweis Egyetem II. Belgyógyászati Klinikája és a Magyar Endokrinológiai Társaság közös szakmai fóruma, az Endokrinológiai Továbbképző Tanfolyam ebben az évben 13. alkalommal kerül megrendezésre. Az eddigi 12 tanfolyam fő szervezője Dr. Rácz Károly professzor úr volt. Sajnálatosan korai halála miatt ez lesz az első olyan tanfolyam, amit a professzor úr részvétele nélkül kell megrendeznünk. Emlékének adózva a tanfolyamot mostantól

Rácz Károly Endokrinológiai Továbbképző Tanfolyamnak nevezzük.

Az eddigi évek sikeres tanfolyamainak hagyományát folytatva a tanfolyam fő céljának továbbra is a korszerü, a klinikai gyakorlatban is használható ismeretek átadását tekintjük. A gyakori betegségekre helyezzük a fő hangsúlyt e betegségek felismerése és kezelése terén, de több ritka, érdekes kórkép bemutatását is tervezzük. Az endokrinológusok mellett számítunk a családorvosok, belgyógyászok, gyermekgyógyászok, szülész-nőgyógyász szakorvosok és mindazon kollégák részvételére, akik az endokrinológia és anyagcsere-betegségek iránt érdeklődnek.

Több szimpóziumot is tervezünk a korszerű kezelési lehetőségek bemutatása céljából. A tanfolyam végén, hagyományainkhoz híven, tanulságos eseteken keresztül mutatjuk be az endokrinológia szépségeit. A tanfolyam kreditpontos és tesztvizsgával zárul.

A továbbképző tanfolyam orvosok részére PTE ÁOK/2017.II/00038-es kódszámon akkreditált. Sikeres tesztírás esetén az orvos résztvevök 42 kreditpontot szerezhetnek. A kreditpontok az OFTEX portálokon feltüntetett szakképesítéseknél szakma szerinti kötelezö pontszámként kerülnek jóváírásra.

Reméljük, hogy a Rácz Károly Endokrinológiai Továbbképző Tanfolyam résztvevőiként üdvözölhetjük Önöket.

Kollegiális üdvözlettel:

$$
\text { Dr. Igaz Péter } \quad \text { Dr. Tóth Miklós }
$$

Tudományos információ:

\section{Dr. Igaz Péter}

egyetemi tanár

Semmelweis Egyetem, Általános Orvostudományi Kar,

II. Belgyógyászati Klinika

E-mail: igaz.peter@med.semmelweis-univ.hu

Convention Budapest Kft.,

Zimonyi Viktória

1036 Budapest, Lajos u. 66.

Fax: (06 1) 2990187 | Tel./fax: (06 1) 2990184

E-mail vzimonyi@convention.hu

További információk a www.convention.hu honlapon.

\section{Dr. Tóth Miklós}

egyetemi tanár

Semmelweis Egyetem, Általános Orvostudományi Kar,

II. Belgyógyászati Klinika

E-mail: toth.miklos@med.semmelweis-univ.hu

Technikai szervezö: 